\title{
Metoda tamponowa w regeneracji części maszyn
}

\author{
The application of brush plating method \\ in regeneration of machine parts
}

\section{Streszczenie}

W artykule omówiono metodę tamponową i jej możliwości w zakresie regeneracji zużytych elementów maszyn. Przedstawiono zalecenia technologiczne przy nakładaniu powłok. Na wybranych przykładach zaprezentowano praktyczne zastosowania metody tamponowej. W regeneracji metoda tamponowa może stanowić w wybranych przypadkach alternatywę dla metod spawalniczych.

Słowa kluczowe: metoda tamponowa, regeneracja, naprawa, modyfikacja, powłoki
Abstract

The paper presents the brush plating method and its applicability in regeneration of machine parts. This method can be applied for the repair, regeneration and surface modification of machine parts, specifically to build-up the geometry and dimensions of the wornout surfaces. In the first part of the paper the brush plating technology has been presented. The second part of the paper describes selected application of the brush plating method.

Keywords: brush plating, regeneration, repair, modification, coatings

\section{Wstęp}

Metoda tamponowa (ang. brush plating, selective plating, spot plating, swab plating) niejednokrotnie była opisywana na łamach Przeglądu Spawalnictwa $[1,2,3]$. Stanowi ona odmianę nakładania galwanicznego powłok. W metodzie tamponowej roztwór elektrolitu doprowadzany jest do pokrywanej powierzchni za pomocą tamponu (szczotki), będącego w kontakcie z elektrodą. Powierzchnia pokrywana charakteryzuje się odmienną biegunowością w stosunku do powłoki pokrywającej. Źródłem prądu jest prostownik o określonej charakterystyce prądowo-napięciowej. Dzięki swojej prostocie, łatwości opanowania techniki nakładania oraz stosunkowo prostemu wyposażeniu podstawowemu stanowiska, metoda umożliwia efektywne i szybkie nakładanie powłok. Istniejąca znaczna ilość elektrolitów pozwala na nakładanie różnych powłok metalowych (w tym stopowych) i kompozytowych, charakteryzujących się szeregiem właściwości, takich jak: odporność na zużycie, wysoka twardość, odporność na korozję, określona zwilżalność oraz lutowność. Mobilność stosowanych urządzeń dodatkowo podnosi atrakcyjność metody i umożliwia przeprowadzenie nakładania na powierzchnie części maszyn w miejscu jej pracy. $Z$ kolei stosunkowo łatwe zabezpieczanie (maskowanie) powierzchni elementów przed kontaktem z roztworem elektrolitu, a tym samym osadzaniem powłoki w miejscach niepożądanych, pozwala niejednokrotnie prowadzić proces bez konieczności demontażu elementów maszyny czy urządzenia, co dodatkowo zmniejsza koszty oraz minimalizuje czasy przestoju. Zakres stosowania metody tamponowej jest szeroki i obejmuje m.in. modyfikację właściwości powierzchni przez nakładanie powłok dekoracyjnych i powłok technicznych. Może być również stosowana w regeneracji powierzchni elementów maszyn i urządzeń (naprawa łożysk ślizgowych, panewek, wałów cylindrów, tłoków, prowadnic, kół zębatych, matryc) uszkodzonych w wyniku pracy lub losowych zdarzeń. Dużą zaletą metody tamponowej jest brak odkształceń elementów pokrywanych. W literaturze światowej dostępne są informacje o zastosowaniu metody tamponowej jako elementu składowego procesu hybrydowego modyfikacji powierzchni [4].

\section{Ogólne zalecenia technologiczne}

Proces nakładania metodą tamponową powłok na materiał podłoża w celu modyfikacji lub regeneracji obejmuje przeważnie kilka etapów. Pierwszym

Dr inż. Jarosław Grześ - Politechnika Warszawska, dr inż. Maciej Rychlewski - Maciej Rychlewski Biuro Inżynierskie Autor korespondencyjny/Corresponding author. jgrzes@wip.pw.edu.pl 
z nich jest obróbka wstępna, której celem jest przygotowanie powierzchni wyrobu do nakładania powłoki. Można stosować obróbkę mechaniczną, chemiczną lub elektrochemiczną. Obróbka mechaniczna powierzchni powinna zapewnić usunięcie tlenków i innych zanieczyszczeń w warstwie przypowierzchniowej, zaokrąglenie ostrych krawędzi, nadanie powierzchni określonej faktury (np. ozdobnej, co jest często istotne w przypadku powłok o charakterze dekoracyjnym) i chropowatości.

Po przeprowadzonej obróbce mechanicznej należy zadbać o oczyszczenie powierzchni z zanieczyszczeń mechanicznych, tłuszczów, produktów korozji itp. Powyższe zanieczyszczenia można usunąć mechanicznie, chemicznie, elektrochemicznie lub na drodze fizykochemicznej. Proces odtłuszczania wstępnego można przeprowadzić za pomocą np. wapna wiedeńskiego lub rozpuszczalników organicznych. Proces odtłuszczania właściwego powierzchni w przypadku metody tamponowej przeprowadza się najczęściej elektrochemicznie, stosując odpowiednie roztwory elektrolitów. Działanie roztworów elektrolitów jest dodatkowo intensyfikowane poprzez wydzielanie się wodoru (odtłuszczenie katodowe) lub tlenu (odłuszczanie anodowe). Ze względu na większą ilość wydzielającego się gazu odłuszczanie katodowe jest znacznie efektywniejsze. Niestety, przy jego stosowaniu istnieje możliwość nawodorowania powierzchni i wystąpienie kruchości wodorowej.

Następnie przeprowadza się aktywację powierzchni w celu usunięcia stanu pasywnego powierzchni pokrywanej. Efekt końcowy aktywacji zależy m.in. od rodzaju materiału podłoża, przeprowadzonej obróbki cieplnej, użytego elektrolitu oraz czasu trwania procesu aktywowania. W zależności od materiału podłoża stosuje się jeden lub kilka elektrolitów. Po zakończeniu aktywacji powierzchnię należy dokładnie opłukać, a następnie niezwłocznie przystąpić do nakładania właściwej powłoki. Elektrolity stosowane w metodzie tamponowej do odtłuszczania i aktywacji należą do grupy I. elektrolitów do przygotowania powierzchni. Przykładem elektrolitów należących do tej grupy są m.in. elektrolity Electroclean \#0, \#1, Activator \#1, \#2,\#3 [5].

Nakładana powłoka może być jedno- lub wielowarstwowa. W większości przypadków regeneracji powierzchni wyrobów stosuje się powłoki wielowarstwowe. Najczęściej stosuje się kolejno trzy elektrolity należące do II. grupy (elektrolity do nakładania powłok). Za pomocą pierwszego z nich nakłada się cienką warstwę podkładową (podwarstwę), której zadaniem jest zwiększenie przyczepności następnych warstw do materiału podłoża. Następnie odbudowuje się uszkodzoną powierzchnię, nakładając warstwy wypełniające. Stosowanym często $w$ tym celu jest elektrolit umożliwiający nakładanie miedzi. Po odbudowaniu powierzchni nakładana jest warstwa mająca zapewnić wymagane właściwości użytkowe, takie jak np. twardość czy odporność na korozję. Na koniec, jeżeli zachodzi taka konieczność, przeprowadza się obróbkę wykańczającą nałożonej powłoki np. przez polerowanie elektrochemiczne tamponowe.
Nie jest możliwe opracowanie jednej, uniwersalnej technologii regeneracji powierzchni części maszyn za pomocą metody tamponowej. Wynika to z różnorodności przypadków spotykanych w praktyce. W celu prawidłowego opracowania technologii nakładania (sposób obróbki wstępnej, dobór elektrod i elektrolitów, kolejność nakładania warstw i ich grubość, parametry nakładania, obróbka wykańczająca) wymagana jest znajomość wielu czynników ściśle ze sobą powiązanych. Przed przystąpieniem do opracowania szczegółowej technologii regeneracji za pomocą metody tamponowej należy określić:

- zadania, jakie ma spełniać powłoka,

- środowisko pracy powłoki,

- minimalny czas trwałości (pracy) powłoki,

- sposób działania i odpowiedzialność regenerowanej części za właściwe funkcjonowanie maszyny,

- występujące obciążenia działające na powłokę,

- rodzaj materiału podłoża,

- stan powierzchni materiału podłoża,

- kształt regenerowanej powierzchni,

- wielkość istniejących uszkodzeń i ewentualnych ubytków materiału podłoża,

- powierzchnie istotnie ważne,

- możliwość demontażu części.

Przy nakładaniu powłok należy przestrzegać następujących zaleceń:

- temperatura materiału podłoża nie może przekraczać $50^{\circ} \mathrm{C}$,

- uchwyt elektrodowy powinien zostać dobrany w zależności od wielkości elektrody oraz od natężenia prądu nakładania,

- przy nakładaniu ręcznym (nadal najbardziej rozpowszechnionym) wielkość elektrody powinna być tak dobrana, aby powierzchnia styku wynosiła ok. 1/3 powierzchni pokrywanej,

- należy stosować elektrody o kształcie zbliżonym do kształtu powierzchni pokrywanej,

- elektrodę (tampon) względem powierzchni pokrywanej powinno się prowadzić ruchem płynnym, jednostajnym, z tak dobraną prędkością, aby nie występowały przypalenia powłoki,

- wilgotność tamponu powinna być stała, co można zapewnić poprzez zastosowanie specjalnych uchwytów, umożliwiających ciągłe podawanie elektrolitu,

- należy unikać nadmiernego nacisku tamponu na powierzchnię pokrywaną,

- zakres temperatury pracy elektrolitu powinien wynosić $25 \div 80^{\circ} \mathrm{C}$,

- grubość warstwy nie powinna być większa od grubości granicznej (tzw. grubość bezpieczna). Wartość grubości bezpiecznej zależy od zastosowanego elektrolitu.

Przy nakładaniu powłok istnieje zależność między jakością powłoki a parametrami nakładania i stanem elektrolitu. Kontrola parametrów nakładania w trakcie procesu na ogół nie stwarza problemów. Natomiast problemem jest ocena stopnia zużycia elektrolitu w warunkach warsztatowych. Występuje on w przypadku zastosowania zamkniętego obiegu elektrolitu lub zastosowaniu elektrolitu wcześniej używanego. 
Kompleksowa ocena jakości elektrolitu możliwa jest tylko w warunkach laboratoryjnych, po przeprowadzeniu szeregu badań. W warunkach warsztatowych możemy tylko w sposób przybliżony określić zużycie elektrolitu, wykorzystując $w$ tym celu jego właściwości, takie jak pH, gęstość i klarowność. Również zmiany w wyglądzie nakładanej powłoki (np. spadek połysku powłoki, występowanie plam) oraz zmniejszenie szybkości jej narastania świadczą o postępującym zużyciu elektrolitu.

Istotnym elementem procesu nakładania jest zapewnienie właściwych warunków pracy operatora i przestrzeganie ogólnych i szczegółowych zasad BHP, obowiązujących przy nakładaniu powłok elektrolitycznych.

\section{Przykłady zastosowania metody tamponowej}

Jeżeli pokusić się o najbardziej ogólne określenie praktycznego aspektu technologii metalizacji elektrochemicznej, to można by stwierdzić, że jest ona bardziej technologią naprawczą niż produkcyjną. Przemawia za tym stosunkowo duża pracochłonność poszczególnych operacji, niezbędna ciągła kontrola kilku parametrów technologicznych, potrzeba optycznej oceny skutków operacji i ewentualna natychmiastowa korekta sposobu działania. Tym niemniej spotyka się niekiedy w przemysłowej produkcji wielkoseryjnej zautomatyzowane stanowiska, gdzie technologia ta, przy starannie dobranych parametrach i sekwencji poszczególnych operacji, zdaje egzamin. Tak więc udaje się osiągnąć w sposób powtarzalny powłokę o zadanych własnościach, detal ma wymiary końcowe zgodne $z$ dokumentacją, a przyjęta procedura kontroli jakości detali nie generuje zbyt wielkich kosztów. Producenci w ciągłym wyścigu konkurencyjnym zachowują w tajemnicy takie stanowiska, jednakże wiadomo jest, że można je spotkać u niektórych producentów detali do produkcji samochodów oraz w produkcji komponentów elektronicznych. Jednakże udział aplikacji w produkcji w porównaniu z aplikacjami warsztatowymi, naprawczymi jest relatywnie niski.

Poniżej opisano kilka wybranych przykładów napraw wykorzystujących metodę tamponową, dokonanych w ostatnim okresie czasu.

Nieustanne awarie i uszkodzenia sprzętu budowlanego, dźwigów i wózków widłowych sprawiają, że warsztaty naprawcze hydrauliki siłowej, również warsztaty metalizacji elektrochemicznej, mają zlecenia przez okrągły rok. Naprawy tłoczysk i innych elementów hydrauliki siłowej stały się właściwie standardem. Opracowano technologię wypełnienia metalem powstałego ubytku (rysy lub ubicia) w tłoczysku, ręcznego przeszlifowania na zgodność $z$ wymiarem bazowym i nałożenia końcowej warstwy metalu o wysokiej twardości i odporności na ścieranie.

$\mathrm{Na}$ rysunku $1 \mathrm{a}$, b przedstawiono naprawę uszkodzonego tłoczyska siłownika maszyny budowlanej. Uszkodzenie tłoczyska nastąpiło na skutek uderzenia spadających fragmentów burzonej ściany. Wskazana była niezwłoczna naprawa, ponieważ dalsza praca si- łownika doprowadziłaby do stopniowego zniszczenia uszczelnienia, nasilenia wycieku oleju hydraulicznego, a w końcowym efekcie do obniżenia ciśnienia roboczego w cylindrze i jego nieprawidłowej pracy. Maszyna zjechała z placu budowy na kilka godzin do warsztatu, gdzie bez demontażu tłoczyska dokonano szybkiej jego naprawy. Ponadto okazało się, że uszczelnienie nie zostało jeszcze uszkodzone, więc jego wymiana nie była konieczna i sprawna maszyna wyjechała niezwłocznie z powrotem do pracy. Zastosowanie metody tamponowego nakładania powłok pozwoliło na zminimalizowanie kosztów przestoju oraz naprawy uszkodzonego tłoczyska. Okazało się tańsze od wymiany całego tłoczyska na nowe oraz tańsze od naprawy klasycznej obejmującej zeszlifowanie całej powierzchni i pokrycie jej nową powłoką chromu technicznego. Ponadto uniknięto kosztów wymiany uszczelnienia, a cała operacja zamknęła się w czasie kilku godzin.

Kolejny przykład naprawy, tym razem tłoczyska siłownika koparki, przedstawiono na rysunku $1 \mathrm{c}$. Widoczne uszkodzenia były stosunkowo płytkie - zaledwie 0,1-0,2 mm. Widoczna jest pierwsza faza naprawy - oszlifowanie uszkodzeń. Naprawa przebiegła bez żadnych problemów.
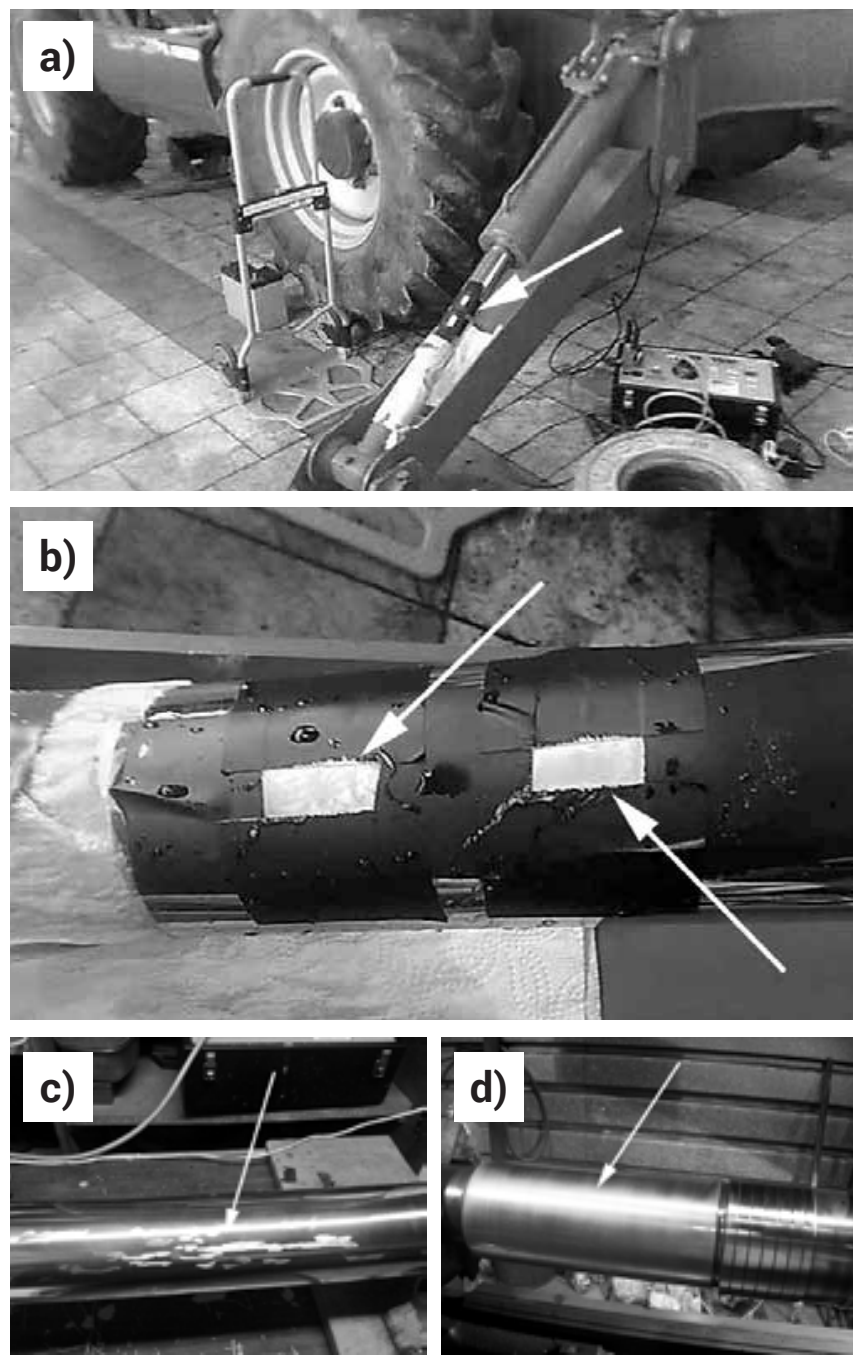

Rys. 1. Przykłady napraw przeprowadzonych za pomocą metody tamponowej (opis w tekście)

Fig. 1. Repair and regeneration of machine parts by brush plating method (see description in text) 

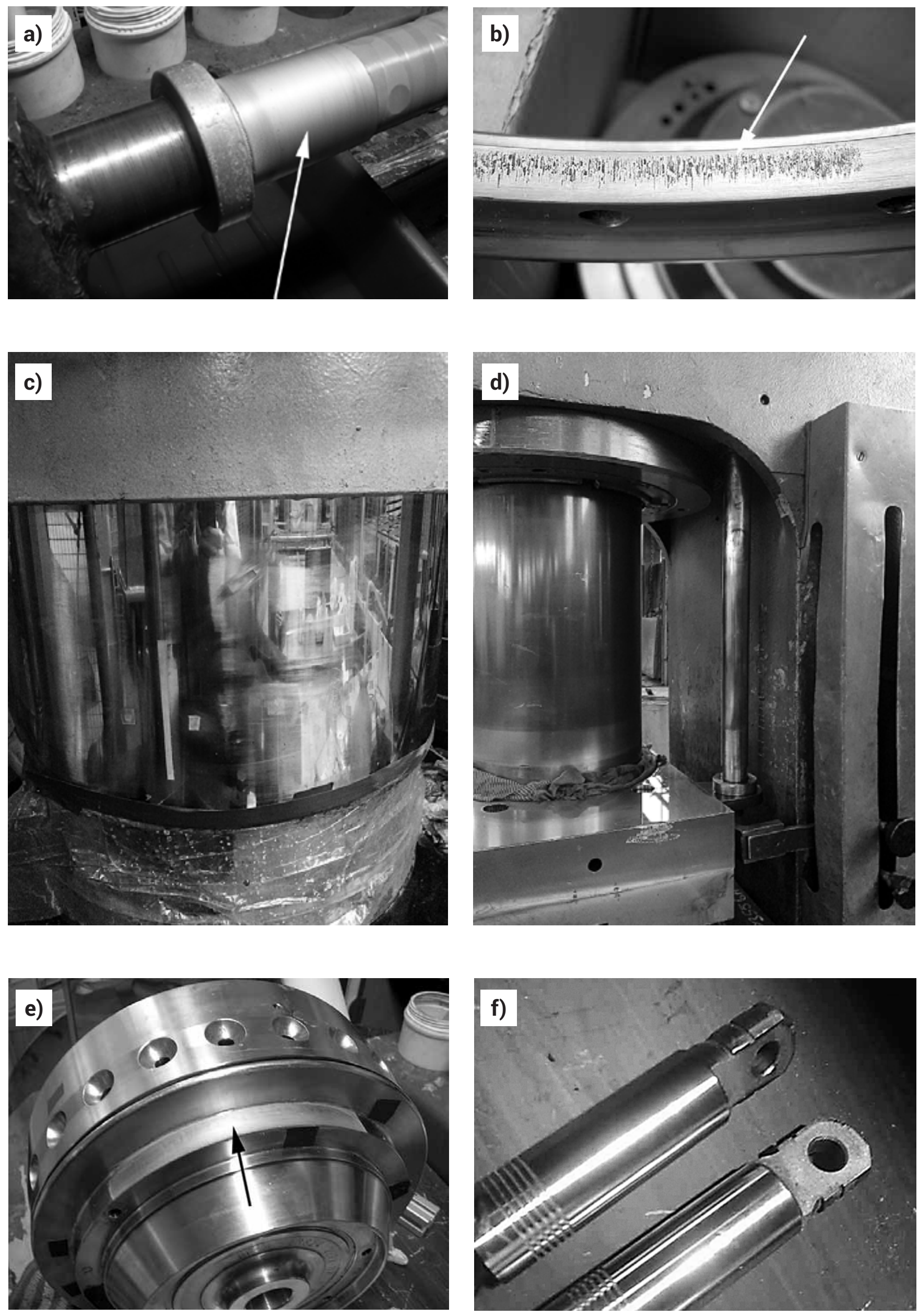

Rys. 2. Przykłady napraw przeprowadzonych za pomocą metody tamponowej (opis w tekście)

Fig. 2. Repair and regeneration of machine parts by brush plating method (see description in text) 

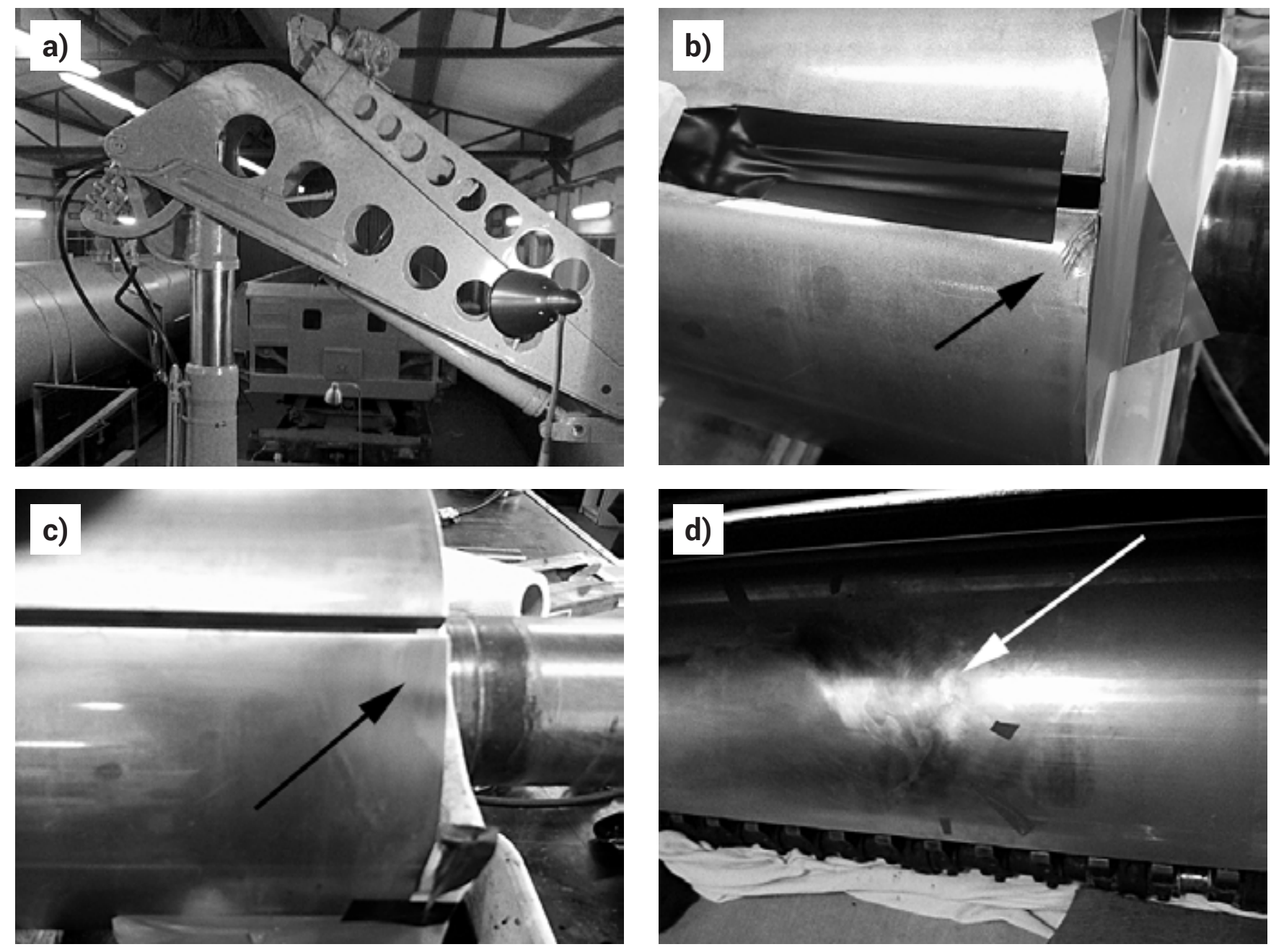

Rys. 3. Przykłady napraw przeprowadzonych za pomocą metody tamponowej (opis w tekście)

Fig. 3. Repair and regeneration of machine parts by brush plating method (see description in text)

Innym, dość trudnym przypadkiem, była naprawa uszkodzonego bijaka młota hydrauliczno-pneumatycznego - rysunek $1 \mathrm{~d}$. Młoty takie stosowane są do wyburzeń starych budynków i konstrukcji, kruszenia nawierzchni itp. Bijak o masie ok. $150 \mathrm{~kg}$ wykonuje ruchy posuwisto-zwrotne z częstotliwością do 6 na sekundę. Część powierzchni została wytarta przez zanieczyszczenia, które przedostały się do oleju hydraulicznego. Nałożona powłoka narażona jest na ciągłe obciążenie wynikające z przyśpieszeń i opóźnień pracującego bijaka. Wytrzymuje te warunki pracy już 3 lata. Dzięki naprawie właściciel zaoszczędził kilka tysięcy euro.

W jednym z zakładów metalurgicznych pewna firma serwisowa podjęła się remontu starej, japońskiej piły. Po jej demontażu okazało się, że tłoczysko (rys. 2a) w siłowniku dwustronnego działania jest silnie skorodowane. Nie wchodził w grę zakup nowego tłoczyska ani jego skopiowanie ze względu na znaczne koszty i niemożność dotrzymania terminu naprawy. Podjęta ostrożna próba napawania i późniejszego zeszlifowania też zawiodła ze względu na odkształcenia i nie najlepszy stan leciwego detalu. Jedyną dopasowaną w tym przypadku technologią okazała się metoda tamponowa. Naprawa trwała dwa dni, a jej efekt zachwycił nawet doświadczonych mechaników.
Osobną grupę klientów stanowią właściciele pras i ekstruderów. Dają się tu zauważyć dwa podejścia do zagadnienia remontów. Jedni pracują bez żadnego remontu takiego urządzenia aż do całkowitego zniszczenia tłoczyska czy nurnika, co najwyżej w odstępie roku lub dwóch wymieniają uszczelnienia, narzekając przy tym na coraz gorszą jakość jego materiału. Druga grupa wykazuje wyższy poziom techniczny i lepiej kalkuluje koszty, tak jak zrobił to właściciel prasy hydraulicznej przedstawionej na kolejnym zdjęciu (rys. 2d). Naprawa tłoczyska tej prasy kosztowała dokładnie tyle samo, ile jednorazowa wymiana uszczelnienia. Jego następna wymiana będzie prawdopodobnie niezbędna za kilka lat. Natomiast podejmowane wcześniej próby napraw za pomocą żywic i klejów musiały być powtarzane co kilka miesięcy. Materiał wypełnienia kruszył się, wypadał i co gorsza dostawał się pod uszczelnienie, niszczył je i rysował tłoczysko.

Jeszcze wyższe wymagania stawiane są w przypadku pras $w$ przemyśle drzewnym (rys. 2c). Przy produkcji płyt meblowych oprócz wysokiego ciśnienia oleju (360 do 400 atmosfer w zależności od fazy cyklu) cały stół pod prasą podgrzany jest do ok. $140^{\circ} \mathrm{C}$. Również $w$ tym przypadku naprawione elementy nie wymagają już od kilku lat wymiany uszczelnień.

$\mathrm{Na}$ rysunkach $2 \mathrm{~b}$, e pokazano uszkodzenia i regenerację elementów wirówki mazutu niezbędnej 
na statkach. Wytarciu ulegaja m.in. wewnętrzne powierzchnie pierścieni (rys. 2b - widok przed naprawą) oraz zewnętrzne powierzchnie bębnów (rys. 2e - powierzchnia w trakcie naprawy). Naprawa przez napawanie i późniejsze szlifowanie do pierwotnego wymiaru jest tu niemożliwa, ponieważ w następstwie lokalnego przegrzania pierścień traci kształt. Metoda tamponowa jest tu bezkonkurencyjna. Nałożone powłoki narażone są na znaczne siły odśrodkowe, ponieważ bębny wirują z prędkością ok. 10.000 obr./min.

Innym przykładem zastosowania metody tamponowej jest regeneracja powierzchni suwaków w rozdzielaczach hydraulicznych. Są ukryte wewnątrz korpusu rozdzielacza, więc nie podlegają bezpośrednim uszkodzeniom mechanicznym. Natomiast wycierają się z powodu przedostających się z zewnątrz zanieczyszczeń. Na rysunku $2 f$ przedstawione są suwaki, które po naprawie odzyskały poprzedni kształt i wymiar. Sprawa zachowania wymiaru po naprawie jest tu szczególnie istotna, jako że pracują one na cieniutkiej warstewce oleju w bezpośrednim kontakcie z metalem korpusu (bez uszczelnień elastycznych).

Powłoki nakładane metodą tamponową nie tylko pozwalają na wypełnienie ubytków czy poprawienie właściwości mechanicznych powierzchni detalu, ale również służą jako zabezpieczenie antykorozyjne. Przykładem jest naprawa tłoczyska siłownika głównego i pomocniczego w żurawiku na drezynie kolejowej (rys. 3a). Prace wykonano bez demontażu, na miejscu u klienta.
Sen z oczu właścicielom drukarni spędzają uszkodzone cylindry maszyn drukarskich. Cylindry stanowią bowiem o jakości druku, a tymczasem właśnie pomiędzy nie wpada najczęściej jakaś nakrętka, kulka z łożyska czy klucz imbusowy, powodując odcisk na powierzchni roboczej. Służba utrzymania ruchu drukarni stara się dokonać awaryjnej naprawy takiego uszkodzenia, najczęściej przy pomocy różnych żywic lub klejów. Skutek jest niestety krótkotrwały i w najmniej właściwym momencie, podczas druku odpowiedzialnego zlecenia klej ulega wykruszeniu i maszynę należy zatrzymać. W przeciwieństwie do takich sposobów naprawy wypełnienie metalem i precyzyjne przeszlifowanie rozwiązuje problem. Na zdjęciach widoczny jest fragment cylindra maszyny Heidelberg przed (rys. 3b) i po naprawie (rys. 3c) przeprowadzonej przy wykorzystaniu metody tamponowej.

Najwyższy podziw i uznanie wśród serwisantów maszyn drukarskich budzą naprawy wielkopowierzchniowe, jak ta, przedstawiona na rysunku 3d. Uszkodzenie spowodował zwinięty arkusz papieru, który przeleciał przez wszystkie sekcje maszyny. W następstwie tego uległy wgnieceniu duże (ok. 0,08 - 0,1 $\mathrm{m}^{2}$ ), nieregularne obszary cylindrów dociskowych. Klasyczna naprawa polega na demontażu cylindrów, przesłaniu do specjalizowanego zakładu remontowego lub do producenta maszyny celem precyzyjnego zeszlifowania całej powierzchni, chromowaniu całej powierzchni, ew. ponownemu szlifowaniu, polerowaniu i ponownym montażu, co zabiera zwykle kilka tygodni. Koszt wielokrotnie wyższy w porównaniu z metodą tamponową.

\section{Podsumowanie}

Na podstawie przedstawionych przykładów wykonanych napraw można stwierdzić, iż metoda tamponowa posiada duże znaczenie praktyczne i może być stosowana w modyfikacji i regeneracji powierzchni części maszyn. Jej zastosowanie w wielu przypadkach może przynieść wymierne korzyści materialne. Może jednocześnie znacząco skrócić okresy przestoju maszyny związane z koniecznością demontażu uszkodzonych części i ich naprawy. Szeroka gama dostępnych elektrolitów, a tym samym możliwość uzyskiwania powłok o określonych właściwościach, możliwość nakładania powłok na różnorodne materiały, łatwość maskowania powierzchni nieistotnych i mobilność dodatkowo podnoszą atrakcyjność metody.

Technologia nakładania powłok wykorzystująca metodę tamponową posiada olbrzymi potencjał. Jej pola zastosowań zależą w gruncie rzeczy od poznania jej specyfiki oraz od wyobraźni inżynierów. Należy ubolewać, że w dalszym ciągu jest tak mało znana w naszym kraju.

\section{Literatura}

[1] J. Grześ, "Badania powłok metalowych nakładanych metodą tamponową", Przegląd Spawalnictwa nr 7-9, 27-29, 1991.

[2] J. Grześ, "Warstwy pośrednie nakładane metodą tamponową", Przegląd Spawalnictwa nr 6, 48-52, 2011.

[3] J. Grześ, "Odporność korozyjna wybranych powłok nakładanych metodą tamponową", Przegląd Spawalnictwa nr 2, 1418, 2014.
[4] S.J. Dong, Y. Zhou, Y.W. Shi, L. Fan, “A New Hybrid Process for Surface Modification by Combining Brush Plating with Nitrocarburizing", Metallurgical and Materials Transactions A, vol. 33, 2240-2244, 2002.

[5] "Brush plating solutions instruction manual", China National Machinery Import \& Export Corporation, Beijing Branch. 